\title{
Mouse Hemokinin-1 Decapeptide Subjected to a Brain-specific Post-translational Modification
}

\author{
GEORGIA DELICONSTANTINOS ${ }^{1}$, STEPHEN BARTON ${ }^{2}$, MIKHAIL SOLOVIEV ${ }^{3}$ and NIGEL PAGE ${ }^{1}$ \\ ${ }^{1}$ School of Life Sciences, Kingston University, London, U.K.; \\ ${ }^{2}$ School of Pharmacy \& Chemistry, Kingston University, London, U.K.; \\ ${ }^{3}$ School of Biological Sciences, Royal Holloway University of London, London, U.K.
}

\begin{abstract}
Background/Aim: The tachykinin mouse hemokinin-1, expressed by the mouse Tac4 gene, produces either analgesia or nociception, interacting with the neurokinin 1 receptor. TAC4 precursor processing is not identical to the processing of the TAC1 precursor, for the release of substance $P$ (amidated undecapeptide). The characterization of the mouse hemokinin-1 sequence was required. Materials and Methods: We developed antitachykinin-specific antibodies for the immunoaffinity purification of tachykinins. Results: Using MALDI-ToF, we identified mouse hemokinin-1 as an amidated decapeptide expressed in murine brain and periphery. Furthermore, we interestingly observed an additional mass peak corresponding to acetylated mouse hemokinin-1 and this post-translational modification is brain-specific, not detected in the periphery. Conclusion: We suggest that the $N$-terminal acetylation of the peptide provides greater potency for ligand-receptor interactions during neural cell signaling.
\end{abstract}

Tachykinins as a vast family of highly conserved peptides share the signature C-terminal motif FXGLM-NH2 (where $\mathrm{X}$ in mammals is $\mathrm{F}, \mathrm{Y}, \mathrm{V}$; in fish, $\mathrm{H}, \mathrm{I}$, and in ascidians $\mathrm{T}$ ) (1-3). The tachykinin mouse hemokinin-1 (mHK-1) discovered as an autocrine factor during pro-B lymphocyte differentiation introduced the group of endokinins (4) which also comprises human HK-1 (5), and its extended forms endokinin A (EKA) and endokinin (EKB) (6) or truncated

This article is freely accessible online.

Correspondence to: Dr. Georgia G. Deliconstantinos, Argyrokastrou St. 5, 14572, Attiki, Greece. Tel: +30 6972080302, e-mail: ginadeli@hotmail.com

Key Words: Mouse hemokinin-1, substance $\mathrm{P}$, tachykinins, N-terminal acetylation, anti-tachykinin antibodies, RP-HPLC, MALDI-ToF. forms such as the tachykinin human hemokinin (hHK-1) (411) (7). Tachykinins act as agonists on the three mammalian tachykinin receptors neurokinin 1, 2, 3 (NK1, NK2, NK3) with different potencies $(5,8)$. The hydrophobic C-terminal tachykinin motif activates the receptor, and the C-terminal amidation is crucial for activation $(9,10)$. Binding studies on the NK1 receptor showed mHK-1 as having similar binding affinity on this receptor as substance P (SP) (11-13) and a similar affinity for each of the mouse, rat and human NK1 receptors $(5,7,14)$.

The opposite effects of mHK-1 and SP in thermal hyperalgesia, have suggested that the two peptides could bind to different subtypes of the NK1 receptor $(15,16)$. The activation of $\mathrm{NK} 1$ receptor is related to the release of endogenous proopiomelanocortin, as well as the increased expression levels of the $\mu$-opioid receptor in analgesia (17). Moreover, it was reported that the $\mathrm{N}$ - and C-terminal fragments of the mHK-1 elicited opposite biological effects (i.e. inhibition or induction of pruritus) when administered in rats, through the activation of the NK1 receptor (18). Recent evidence showed anxiolytic and anti-depressant-like actions for mHK-1 (19). The nociceptive behaviors induced by $\mathrm{mHK}$ 1 were inhibited by NMDA receptor antagonists. A significant increase in glutamate levels was observed, which was reduced by co-administration with NMDA receptor antagonists, suggesting that mHK-1-induced nociceptive effects may be mediated by the NMDA receptor (20). The Tachykinin receptor-1 (TACR I) gene was found among the neurotoxicityassociated genes in brain tissue that were significantly modulated after irradiation, suggesting that catenin- $\beta 1$ and tumor suppressor-related transcription regulation are significantly activated by radiation and/or minocycline, suggesting minocycline as a potential neuroprotectant against radiation-induced damage (21). Moreover, the TACR3 was shown to be highly expressed in oral squamous cell carcinoma suggesting TAC3 was released by the peripheral sensory nerves which may act in tumor cells and that TACR3 signaling may, in turn, contribute to tumor progression (22). 
In the present study, the characterization of mHK-1 sequence and post-translational modifications were investigated. The rat TAC4 precursor comprises mHK-1 flanked by dibasic KR cleavage sites, releasing the decapeptide SRTRQFYGLM-NH $\mathrm{N}_{2}$. Previous studies $(4,7,8)$ have reported $\mathrm{mHK}-1$ as an undecapeptide suggesting precursor processing occurring between the $\mathrm{K} / \mathrm{R}$ residues of the dibasic cleavage site, hence, purification and identification of the peptide mass was required. Antibodies were raised against EKA/B (GKASQFFGLM-NH ${ }_{2}$ ) that efficiently recognized $\mathrm{mHK}-1$ (SRTRQFYGLM-NH ${ }_{2}$ ) and SP, then purified and immobilized on Sepharose beads, to produce an affinity medium capable of isolating endogenous $\mathrm{mHK}-1$ and SP. Captured peptides were separated on RP-HPLC and detected using MALDI-ToF. We identified mHK-1 as an amidated decapeptide expressed in both brain and spleen with an additional mass peak corresponding to a brain-specific N-terminal acetylation.

\section{Materials and Methods}

Development of anti-tachykinin antibodies and determination of their reactivity to the peptides SRTRQFYGLM-NH $\mathrm{H}_{2}$ or RPKPQQFFGLM-NH $\mathrm{H}_{2}$ with antibody-titre curves. All reagents were purchased from Sigma-Aldrich (Gillingham, UK) unless otherwise stated. Tachykinin antisera were raised in sheep as described previously (5). Two animals were inoculated with the antigen EKA/B coupled to BSA (antisera annotated as BO14 and BO16). Plates (Nunc Immobilizer ${ }^{\mathrm{TM}}$ Amino, VWR LTD, Leicestershire, UK) were coated with $200 \mathrm{ng}$ of synthetic peptide. Dilutions of the ovine antisera in albumin-phosphate buffer $\left(0.04 \mathrm{M} \mathrm{Na}_{2} \mathrm{HPO}_{4}, 0.01\right.$ $\mathrm{M} \mathrm{NaH} \mathrm{PO}_{4}$, and $0.5 \%(\mathrm{w} / \mathrm{v}) \mathrm{BSA}$ ) were produced and dispensed in duplicate into the wells. After incubating at room temperature, the wells were washed with buffer $(0.9 \%(\mathrm{w} / \mathrm{v}) \mathrm{NaCl}, 0.01 \%(\mathrm{v} / \mathrm{v})$ Triton X-100) three times. A 1/5,000 dilution of donkey anti-sheep IgG-alkaline phosphatase conjugate in albumin-phosphate buffer was added, incubated for two hours at room temperature and removed. The substrate p-nitrophenyl phosphate was used for the detection of immunoreactivity. Plates were read at $450 \mathrm{~nm}$, and the data were represented as absorbance units.

Purification of anti-tachykinin antibodies recognizing SRTRQFYGLM-NH $\mathrm{H}_{2}$ and SP. Cyanogen bromide-activated Sepharose beads $(1 \mathrm{~g})$ were swollen into a $3.5 \mathrm{ml}$ gel, washed with $1 \mathrm{mM} \mathrm{HCl}$, and then suspended in coupling buffer $\left(0.1 \mathrm{M} \mathrm{NaHCO}_{3}, 0.5 \mathrm{M} \mathrm{NaCl}\right.$, and $0.5 \%(\mathrm{v} / \mathrm{v})$ Tween 20, pH $\sim 9$ ). Synthetic SRTRQFYGLM-NH ( $0.5 \mathrm{mg}$; custom made by Designer Biosciences, Cambridge, UK) and $\mathrm{SP}(0.5 \mathrm{mg})$ were dissolved in $1 \mathrm{ml}$ of the coupling buffer and added into the Sepharose gel (incubated overnight at room temperature). The unbound reactive sites on the Sepharose beads were blocked with glycine (0.2 M, pH $\sim 8$ ), and the gel was loaded onto an Econocolumn fitted with a flow adaptor and $30 \mathrm{~cm}$ of silicon tubing (BioRad, Hertfordshire, UK). Each ovine antiserum $(50 \mathrm{ml})$ containing a protease inhibitor mixture (Roche, West Sussex, UK), $0.18 \mathrm{~g}$ EDTA disodium and $2 \%(\mathrm{w} / \mathrm{v}) \mathrm{NaN} 3$ was loaded onto the column. Three columns volume of washing buffer (PBS containing $0.01 \%$ (v/v) Tween-20) were applied. Two columns volume of elution buffer $(0.1 \mathrm{M}$ citric acid $\mathrm{pH} \sim 2.5)$ were added and incubated for 5 min; the eluted antibodies $(6 \mathrm{ml})$ were immediately neutralized.
Immobilization of anti-tachykinin antibodies on cyanogen bromideactivated Sepharose beads. Cyanogen bromide-activated Sepharose beads $(1 \mathrm{~g})$ were activated and washed with $1 \mathrm{mM} \mathrm{HCl}$ and then suspended in coupling buffer. The immunopurified anti-tachykinin antibodies were diluted in coupling buffer, added into the Sepharose gel and incubated overnight at room temperature. Unbound reactive sites were blocked; the blocking agent was removed, and the antitachykinin antibody-Sepharose conjugates were stored in $5 \mathrm{ml}$ of storage buffer $(1 \mathrm{M} \mathrm{NaCl}$ with $0.02 \%$ (w/v) NaN3 and $1 \mathrm{mM}$ EDTA disodium) at $4^{\circ} \mathrm{C}$.

Isolation of tachykinins by immunoaffinity purification. One rat brain was homogenized using a $10 \mathrm{ml}$ syringe. Two rat spleens were homogenized using a mortar and pestle while keeping tissues frozen in liquid nitrogen. Each homogenized tissue was suspended in $1 \mathrm{ml}$ of extraction buffer (Bennett's solution consisting of, $1 \mathrm{M} \mathrm{HCl}$ containing $5 \%(\mathrm{v} / \mathrm{v})$ formic acid, $1 \%(\mathrm{w} / \mathrm{v}) \mathrm{NaCl}$ and $1 \%(\mathrm{v} / \mathrm{v}) \mathrm{TFA})$ and incubated overnight at $4{ }^{\circ} \mathrm{C}$. The mixture was centrifuged at 7500 $\times g$ for $15 \mathrm{~min}$ and $1 \mathrm{ml}$ of peptide extract was recovered. The peptide extract was diluted in $9 \mathrm{ml}$ of $0.1 \%(\mathrm{v} / \mathrm{v})$ aqueous TFA. The diluted peptide extract was loaded onto a C18 Sep-Pak cartridge (Waters, Hertfordshire, UK) previously primed with methanol and equilibrated with $0.1 \%$ (v/v) TFA). Peptides were eluted with $1 \mathrm{ml}$ of $60 \%(\mathrm{v} / \mathrm{v})$ acetonitrile with $0.1 \%(\mathrm{v} / \mathrm{v})$ TFA, neutralized with $1 \mathrm{M}$ TRIS $\mathrm{pH} \sim 10$ and concentrated under a continuous flow of $\mathrm{N}_{2}$. The peptide extract was incubated with $60 \mu \mathrm{l}$ of anti-tachykinin antibodySepharose beads suspended in binding buffer (10 mM EDTA disodium, $0.01 \%(\mathrm{w} / \mathrm{v})$ octyl $\beta$-D-glucopyranoside, $0.02 \%(\mathrm{w} / \mathrm{v})$ $\mathrm{NaN}_{3}$, and protease inhibitors mixture in PBS). The final volume of the reaction was $500 \mu \mathrm{l}$, which was incubated at room temperature overnight. Next, the beads were washed extensively with working buffer and peptides were eluted incubating with $60 \mu \mathrm{l}$ of $0.5 \%$ (w/v) TFA and centrifuging at $700 \times g$ for $5 \mathrm{~min}$.

Separation of enriched peptides on RP-HPLC and detection on MALDI-ToF. RP-HPLC was performed using a Waters 600E system controller (Millipore, Watford, UK) and a Waters 486 Tunable UV absorbance detector system, with a reversed phase C18 column (Vydac 218TP54, Beckman Coulter, High Wycombe, UK). An aliquot of the rat brain and spleen immunoaffinity eluents was injected into the system, and peptides were eluted with a linear gradient starting at $10 \%$ acetonitrile with $0.04 \%(\mathrm{v} / \mathrm{v})$ TFA, taken to $40 \%$ over $30 \mathrm{~min}$, and kept constant at $100 \%$ for $10 \mathrm{~min}$. The flow rate was set at $0.5 \mathrm{ml} / \mathrm{min}$ and absorbance at $205 \mathrm{~nm}$. Fractions of $250 \mu \mathrm{l}$ were manually collected, and organic solvents were removed under a constant $\mathrm{N}_{2}$ flow. Each $20 \mu \mathrm{l}$ fraction was further concentrated with a ZipTip ${ }_{\mu-\mathrm{C} 18}$ (Millipore, Watford, UK) primed with $50 \%(\mathrm{v} / \mathrm{v})$ methanol with $0.1 \%(\mathrm{v} / \mathrm{v})$ TFA and equilibrated with $0.1 \%$ (v/v) TFA. Peptides were directly spotted, with $\alpha$-Cyano-4hydroxycinnamic acid matrix (Agilent Technologies, Berkshire, UK) dissolved in ethanol with $1 \%$ (v/v) TFA, on an MALDI-ToF plate (ground steel Bruker). Peaks were detected using an MALDI-ToF (Bruker Autoflex III) instrument with FlexControl software.

\section{Results}

Anti-tachykinin antibodies were raised by inoculating two sheep with the same antigen i.e. EKA/B (GKASQFFGLM$\mathrm{NH}_{2}$ ). The anti-sera were capable of recognizing the SP and SRTRQFYGLM-NH $\mathrm{N}_{2}$ peptides. Tachykinins possess a 

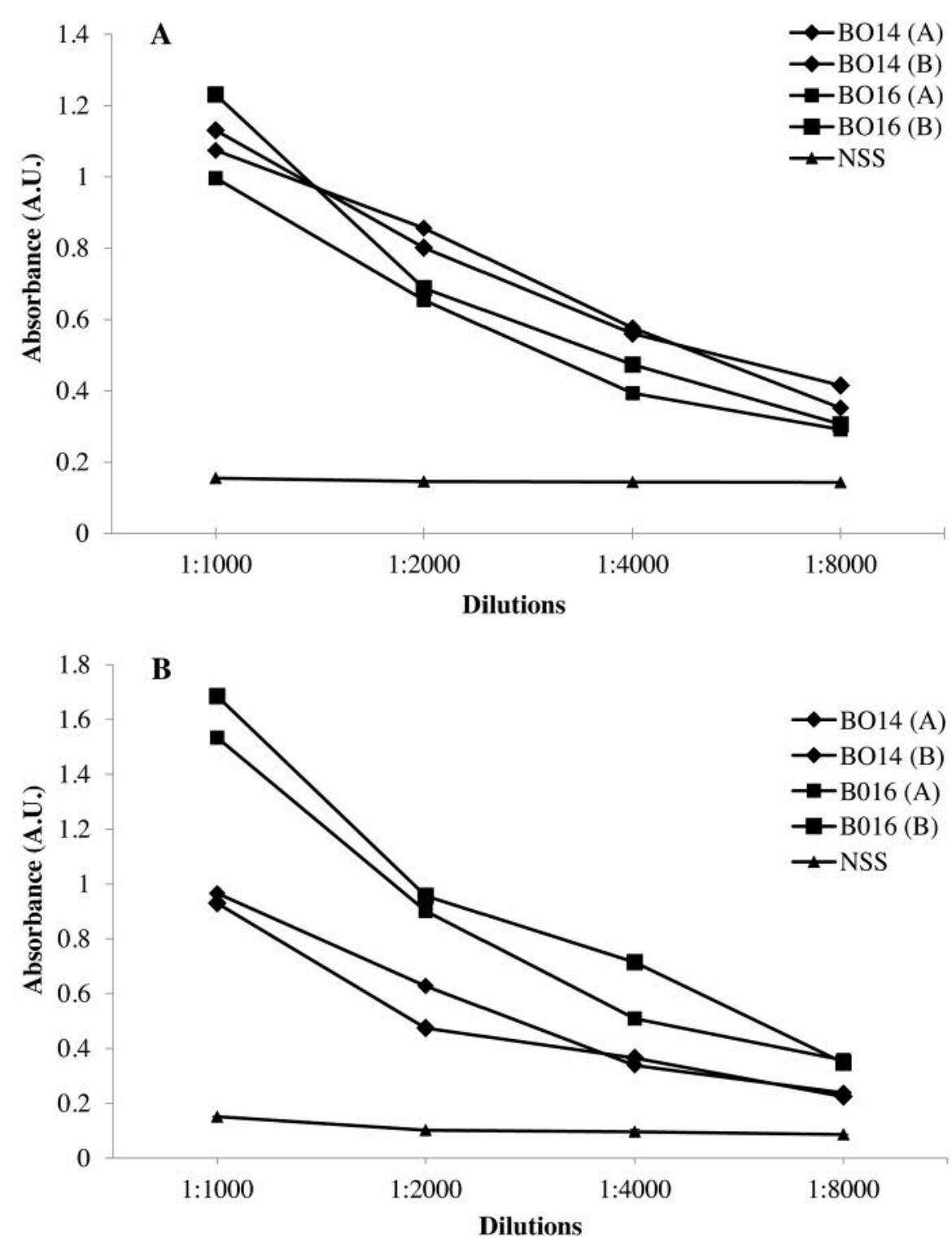

Figure 1. Antibody titre curves of two anti-tachykinin antisera BO16 (squares) and BO14 (diamonds). (A) Binding of the two antisera with SP. The antibody titre curves obtained with normal sheep serum (triangles) were used as a negative control. (B) The antibody titre curves of the same antisera against mHK-1.

backbone on the FXGLM-NH$H_{2}$ motif and a charged amide group that makes this motif region very immunogenic, however, in the present study, a different response was observed, between the two sheep, with respect to the yielded antibody titres against SP and SRTRQFYGLM-NH 2 (Figure $1 \mathrm{~A}$ and B). As it appears in Figure 1B, the BO16 antiserum showed a substantially higher titre of antibodies recognizing SRTRQFYGLM-NH $\mathrm{NH}_{2}$ and $\mathrm{SP}$ as compared to the BO14 antiserum and therefore the BO16 purified antibodies were immobilized to yield an affinity medium.
A RP-HPLC method was developed for the separation of synthetic SRTRQFYGLM-NH ${ }_{2}$ and SP. Figure $2 \mathrm{~A}$ shows the chromatogram of the synthetic SRTRQFYGLM-NH $\mathrm{N}_{2}$ with retention time $1,402 \mathrm{~s}$ and Figure $2 \mathrm{~B}$ shows the chromatogram of the elution of synthetic SP with retention time 1,706 s. The elution fraction and mass of the two peptides was confirmed with MALDI-ToF. The sequence SRTRQFYGLM-NH 2 has a singly-charged mass $[\mathrm{M}+\mathrm{H}]^{+}$ 1257.652 a.m.u. The $[\mathrm{M}+\mathrm{H}]^{+}$of the SP undecapeptide is 1347.735 a.m.u. 

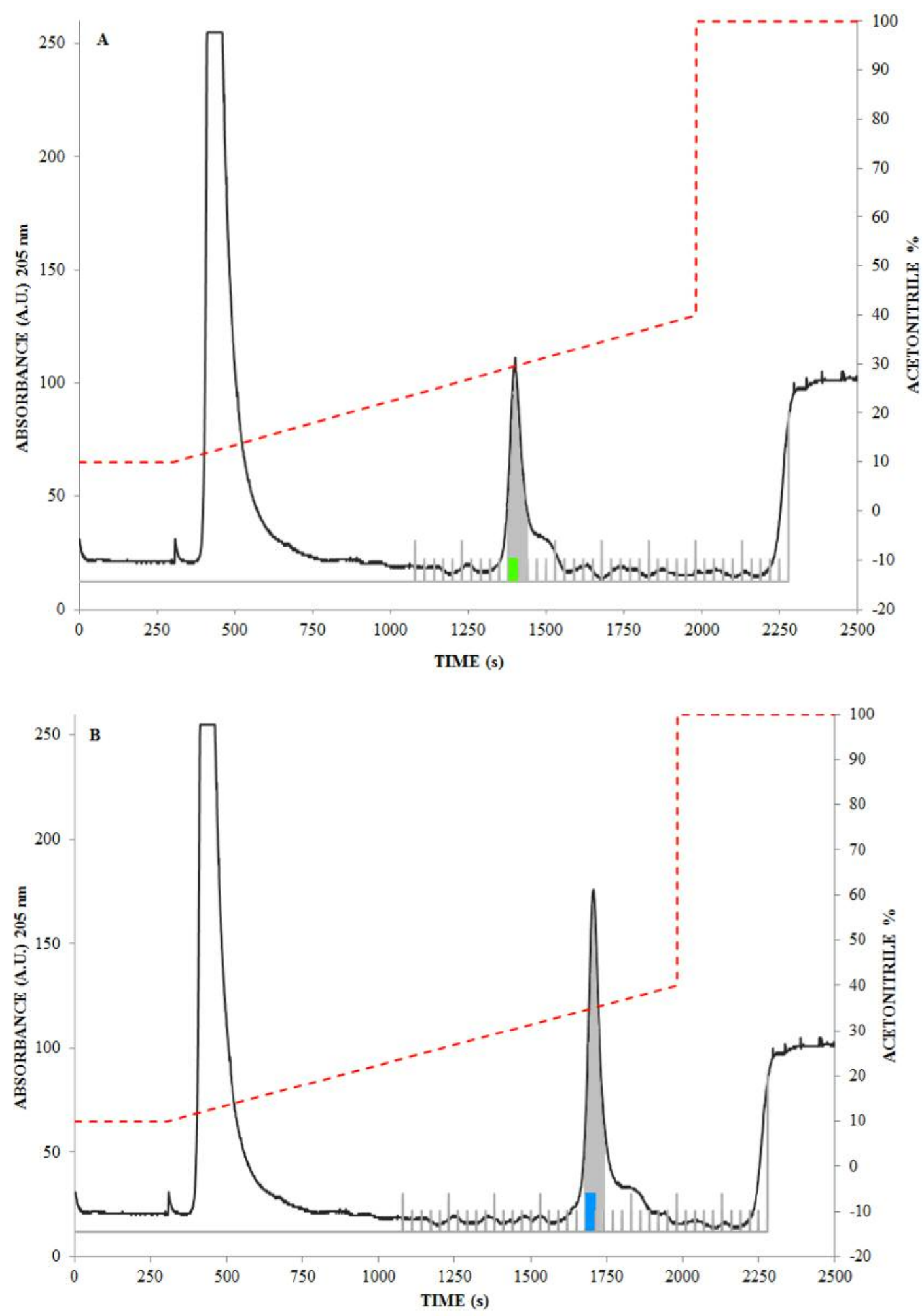

Figure 2. Reversed-phase separation of $m H K-1$ and SP. (A) Elution profile of synthetic mHK-1 (SRTRQFYGLM-NH2). Briefly, the peptide was eluted with a gradient of acetonitrile (dashed red line). The synthetic peptide eluted in fractions 11 and 12 (grey). Forty fractions were collected and the presence of the synthetic $m H K-1$ was confirmed by MALDI-ToF. The endogenous $m H K-1$ was separated using exactly the same instrument settings. The peptide was detected using MALDI-ToF in fraction 11 only (fraction shown in green). (B) The elution profile of synthetic SP, eluted with the same instrument settings as for mHK-1. The synthetic SP eluted in fractions 21 and 22 (grey). Endogenous SP (captured from rat brain and spleen) eluted in fraction 21 (blue). 


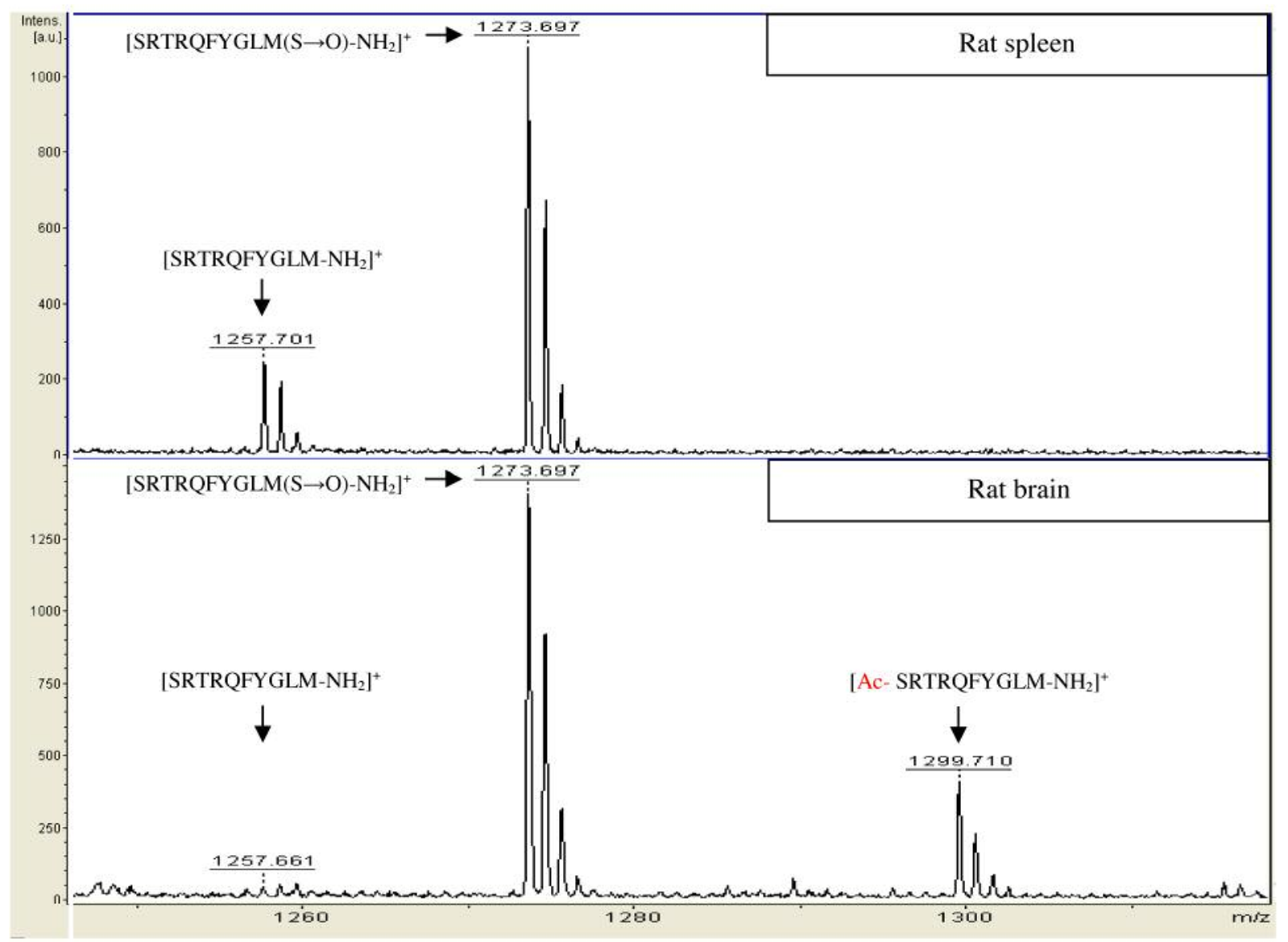

Figure 3. MALDI-ToF ion spectra of $m H K-1$. The upper ion spectrum illustrates peaks detected in the rat spleen. The peak at $\mathrm{m} / z$. 1257.701 is $m H K$ 1, and the peak at $\mathrm{m} / z 1273.697$ is the oxidized form of the same peptide. The lower ion spectrum shows peaks detected in rat brain. The peak at $\mathrm{m} / \mathrm{z}, 1299.710$ is acetylated $\mathrm{mHK}-1$. A post-translationally modified form of endogenous $\mathrm{mHK}-1(\mathrm{~m} / \mathrm{z}, 1299.710)$ corresponds to the acetylation of the $N$-terminal serine.

Table I. Tachykinin peptides (mHK-1 and SP) and their modifications identified by MALDI-ToF.

\begin{tabular}{|c|c|c|c|c|}
\hline Mass detected ${ }^{1}$ & Peptide & Sequence & $\Delta \mathrm{M}(\text { a.m.u. })^{2}$ & Modification \\
\hline 1257.701 & mHK-1 & SRTRQFYGLM-NH ${ }_{2}$ & & Unmodified form. \\
\hline 1273.697 & mHK-1 & SRTRQFYGLM-NH ${ }_{2}(\mathrm{~S} \rightarrow \mathrm{O})$ & 16 & Methionine (sulphur to sulphoxide). \\
\hline 1299.710 & mHK-1 & Ac-SRTRQFYGLM-NH ${ }_{2}$ & 42 & $\mathrm{~N}$-terminal acetylation of serine residue. \\
\hline 1347.894 & SP & RPKPQQFFGLM-NH & & Unmodified form. \\
\hline 1363.886 & SP & RPKPQQFFGLM-NH $\mathrm{N}_{2}(\mathrm{~S} \rightarrow \mathrm{O})$ & 16 & Methionine (sulphur to sulphoxide). \\
\hline
\end{tabular}

${ }^{1}$ Mass indicates $[\mathrm{M}+\mathrm{H}]^{+} ;{ }^{2} \Delta \mathrm{M}$ : indicates the mass difference from the unmodified form, measured in a.m.u. (atomic mass units).

mHK-1 is a decapeptide with a neuropeptide-specific $N$ terminal acetylation. Endogenous tachykinin peptides identified by MALDI-ToF in rat brain and spleen and their modifications are shown in Table I. In Figure 3 endogenous mHK-1 in the rat spleen and brain is shown. The peak seen at $\mathrm{m} / \mathrm{z} 1257.701$ corresponds to the $\mathrm{mHK}-1$ decapeptide, and the peak seen at $\mathrm{m} / \mathrm{z} 1273.697$ is the $\mathrm{mHK}-1$-methionine sulphoxide (SRTRQFYGLM $\left(\mathrm{S} \rightarrow \mathrm{O}\right.$ )- $\mathrm{NH}_{2}$ ). In rat brain, the additional peak seen at $\mathrm{m} / \mathrm{z} 1299.710(\Delta \mathrm{M}+42.049$ a.m.u $)$ is an acetylated form of mHK-1 (Ac-SRTRQFYGLM-NH ${ }_{2}$ ). 


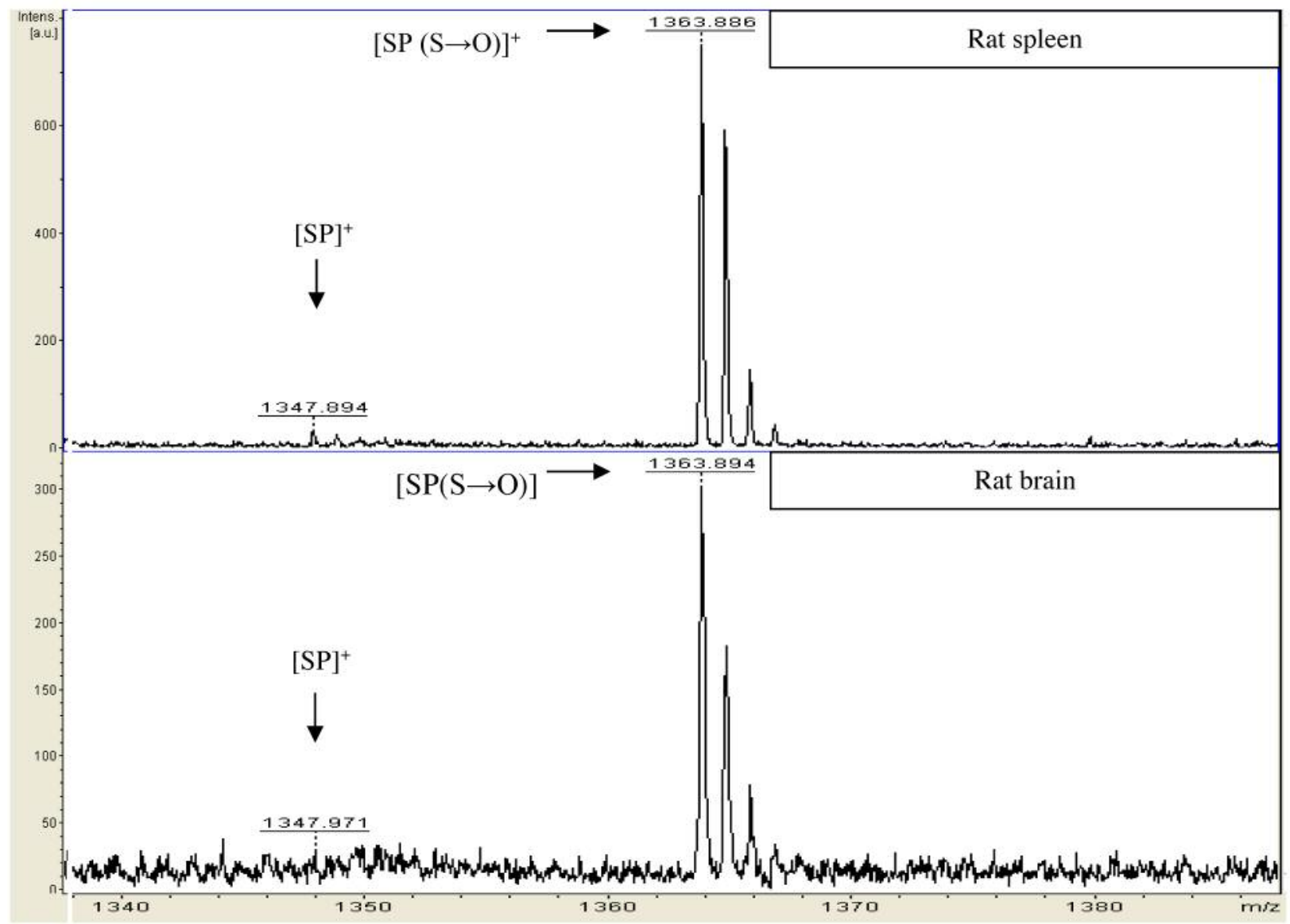

Figure 4. MALDI-ToF ion spectra of SP. The upper ion spectrum illustrates peaks detected in the rat spleen. The peak at $m / z$ 1347.894 is SP, and the peak at $\mathrm{m} / z 1363.886$ is the form where methionine was oxidized (sulphur to sulphoxide). The lower ion spectrum illustrates $S P[(S \rightarrow O)]^{+}$seen at $1363.894 \mathrm{~m} / \mathrm{z}$ detected in rat brain.

The hydroxyl group of the serine is most probably acetylated by specific serine acetyl-transferases.

The expression of $S P$ in rat brain and spleen. Figure 4 shows SP detected in both rat brain and spleen. The $\mathrm{m} / \mathrm{z} 1347.894$ peak corresponds to $[\mathrm{M}+\mathrm{H}]^{+} \mathrm{SP}$ while the peak seen at $\mathrm{m} / \mathrm{z} 1363.886$ is SP-methionine sulphoxide $[\mathrm{SP}(\mathrm{S} \rightarrow \mathrm{O})]^{+}$. Our findings show $\mathrm{SP}$ is abundantly expressed in the rat brain (acting as a neuropeptide) and also SP is expressed in high levels in the rat spleen (acting as an autocrine or paracrine factor).

\section{Discussion}

The sequence of the mHK-1 was deduced from the nucleotide sequence of the novel cDNA, initially named as PPTC and then as Tac4 gene, using the updated standardized nomenclature (23) and was predicted as an amidated undecapeptide RSRTRQFYGLM-NH 2 (4). Therefore, a more definite characterization of the mHK-1 was required i.e. identification of its M.W. and its sequence, as well as any posttranslational modifications apart from the well-established Cterminal amidation. The expression of the mHK-1 in brain has not been clear; Zhang and colleagues reported the Tac4 gene not to be expressed in mouse brain but rather in lymphopoietic cells of the periphery, using a rather insensitive Northern blot analysis; later reports, showed the expression of the Tac4 gene in the rat brain $(7,14,24)$.

Our present study has proven mHK-1 as an amidated decapeptide with an a.a. sequence and M.W. corresponding to SRTRQFYGLM-NH $\mathrm{N}_{2}$ (Figure 3). This finding is not in agreement with the predicted sequence of mHK-1 as

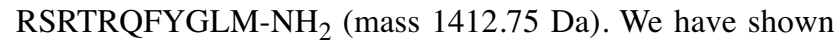
the mass of the mHK-1 as $[\mathrm{M}+\mathrm{H}]^{+} 1257.701 \mathrm{Da}$ same as the theoretical (1257.652 $\mathrm{Da})$. The mHK-1 peptide (SRTRQFYGLM-NH ${ }_{2}$ ) comprises two monobasic cleavage sites at the $\mathrm{R}$ residues, releasing the truncated peptides 
TRQFYGLM-NH $\mathrm{N}_{2}$ (1014.519 Da) and QFYGLM-NH ${ }_{2}$ $(757.37 \mathrm{Da})$. We investigated the trypsinization of synthetic mHK-1 and observed the processing of the peptide indeed occurs in vitro in both monobasic cleavage sites (data not shown). However, the above species were not detected in either of the tissues investigated. Both truncated peptides would show affinity for the NK1 receptor and elicit a biological response as the minimum peptide fragment with the ability to show a similar biological response on the NK receptors as the mature form is the C-terminal hexapeptide (25).

In the present study, SP was also purified from rat brain and rat spleen (Figure 4). This finding is well in line with previous reports showing expression of the Tacl gene in human and rat brain and human spleen $(6,14)$. Moreover, peptide expression studies have detected SP in the brain using mass spectrometry $(26,27)$. Spectra obtained from our study showed that SP was detected with high abundance in both tissues; however post-translational modifications were not identified on SP. A whole rat brain was used comprising different types of cells. Neuronal cells would produce the acetylated form of mHK-1, while immune cells the nonacetylated form. Further pharmacological investigations would elucidate the potency of the mHK-1 decapeptide for the NK1 receptor.

The structure-activity relationship between mHK-1 as a decapeptide and SP as an undecapeptide may be determined by their binding to their respective receptor. In nociception, the cell signaling is through G-proteins, therefore we can suppose that SP acts on the stimulatory subunits of G-proteins and thus increasing the GTPase activity and eventually the $\mathrm{Ca}^{2+}$, while mHK-1 may act on the inhibitory subunits of Gproteins, therefore, a balance system between nociceptors and analgesia may be in place (bystable systems).

Furthermore, in this study we identified mHK-1 in the rat brain comprising a post-translational modification i.e. acetylation of the hydroxyl group of the serine residue. Acetylation occurs by the enzymes $\mathrm{N}$-acetyltransferases most probably in the Golgi apparatus $(28,29)$. The peak of the mHK-1 $[\mathrm{M}+\mathrm{H}]^{+}(1257.661$ a.m.u.) and the acetylated form of mHK-1 (1299.710 a.m.u.) could exist in vivo in a ratio suggesting the existence of an acetylation and de-acetylation system controlled by specific enzymes i.e. serine $\mathrm{N}$ acetyltransferases and de-acetyltransferases. Acetylation is one of the signature post-translational modifications of neuropeptides and the consensus for the biological role of acetylation is greater stability for the peptide and potency of the peptide with its receptor $(30,31)$. Acetylation may protect the peptide from degrading enzymes $e . g$. neprilysin and also acetylation enhances peptide-receptor interactions (32). The TAC4 precursor comprises a signal peptide hence it is directed into Golgi apparatus and stored in vesicles where acetylation occurs (33). Upon release the acetylated mHK-1 activates the NK1 receptor located on the metasynaptic membrane. De-acetylases present on the metasynaptic membrane de-acetylate the peptide, hence, acting as a potential on/off switch of the NK1 receptor (molecular switch).

\section{References}

1 Severini C, Improta G, Falconieri-Erspamer G, Salvadori S and Erspamer V: The tachykinin peptide family. Pharmacol Rev 54: 285-322, 2002.

2 Satake H, Ogasawara M, Kawada T, Masuda K, Aoyama M, Minakata $\mathrm{H}$ and Chiba T: Tachykinin and tachykinin receptor of an ascidian, Ciona intestinalis: evolutionary origin of the vertebrate tachykinin family. J Biol Chem 279: 53798-53805, 2004.

3 Mi X, Yu H, Jia P, Zhang Z, Zhang L and Liu J: Two tachykininlike peptides from skin secretions of Danio rerio. J Pept Sci 16: 81-84, 2010.

4 Zhang Y, Lu L, Furlonger C, Wu GE and Paige CJ: Hemokinin is a hematopoietic-specific tachykinin that regulates $\mathrm{B}$ lymphopoiesis. Nature Immunol 1: 392-397, 2000.

5 Page NM, Bell NJ, Gardiner SM, Manyonda IT, Brayley KJ, Strange PG and Lowry PJ: Characterization of the endokinins: Human tachykinins with cardiovascular activity. Proc Natl Acad Sci 100: 6245-6250, 2003.

6 Page NM: Characterization of the gene structures, precursor processing and pharmacology of the endokinin peptides. Vascul Pharmacol 45: 200-208, 2006.

7 Kurtz MM, Wang R, Clements MK, Cascieri MA, Austin CP, Cunningham BR and Chicchi GG: Identification, localization and receptor characterization of novel mammalian substance Plike peptides. Gene 296: 205-212, 2002.

8 Page NM: New challenges in the study of the mammalian tachykinins. Peptides 26: 356-368, 2005.

9 Beaujouan JC, Torrens Y, Saffroy M, Kemel ML and Glowinski J: A 25-year adventure in the field of tachykinins. Peptides 25: 339-357, 2004.

10 Pennefather JN, Lecci A, Candenas ML, Patak E, Pinto FM and Maggi CA: Tachykinins and tachykinin receptors: a growing family. Life Sci 74: 1445-1463, 2004.

11 Morteau O, Lu B, Gerard C and Gerard NP: Hemokinin-1 is a full agonist at the substance P receptor. Nat Immunol 2: 1088, 2001.

12 Bellucci F, Carini F, Catalani C, Cucchi P, Lecci A, Meini S and Patacchini R: Pharmacological profile of the novel mammalian tachykinin, hemokinin 1. Br J Pharmacol 135: 266-274, 2002.

13 Camarda V, Rizzi A, Calo G, Guerrini R, Salvadori S and Regoli D: Pharmacological profile of hemokinin 1: a novel member of the tachykinin family. Life Sci 71: 363-370, 2002.

14 Duffy RA, Hedrick JA, Randolph G, Morgan CA, CohenWilliams ME, Vassileva G, Lachowicz JE, Laverty M, Maguire M, Shan LS, Gustafson E and Varty GB: Centrally administered hemokinin-1 (HK-1), a neurokinin NK1 receptor agonist, produces substance P-like behavioral effects in mice and gerbils. Neuropharmacology 45: 242-250, 2003.

15 Watanabe C, Mizoguchi H, Yonezawa A and Sakurada S: Characterization of intrathecally administered hemokinin-1induced nociceptive behaviors in mice. Peptides 31: 1613-1616, 2010 . 
16 Sunakawa N, Naono R, Ikeda T, Matsushima O, Sakoda S and Nishimori T: The amino-terminal region of hemokinin-1 regulates the induction of thermal hyperalgesia in rats. Neuropeptides 44: 273-278, 2010.

17 Xia RL, Fu CY, Zhang SF, Jin YT and Zhao FK: Study on the distribution sites and the molecular mechanism of analgesia after intracerebroventricular injection of rat/mouse hemokinin-1 in mice. Peptides 43: 113-120, 2013.

18 Naono-Nakayama R, Ikeda T, Matsushima O, Sameshima H, Takamiya K, Funahashi H, Nishimori T: An amino-terminal fragment of hemokinin-1 has an inhibitory effect on pruritic processing in rats. Neuroscience 259: 172-183, 2014.

19 Borbély É, Hajna Z, Nabi L, Scheich B, Tékus V, László K, Ollmann T, Kormos V, Gaszner B, Karádi Z, Lénárd L, Paige CJ, Quinn JP, Szolcsányi J, Pintér E, Keeble J, Berger A and Helyes Z: Hemokinin-1 mediates anxiolytic and anti-depressantlike actions in mice. Brain Behav Immun 59: 219-232, 2017.

20 Watanabe C, Mizoguchi H, Bagetta G, Sakurada S: Involvement of spinal glutamate in nociceptive behaviour induced by intrathecal administration of hemokinin-1 in mice. Neurosci Lett 617: 236-239, 2016.

21 Mehrotra S, Pecaut MJ and Gridley DS: Minocycline modulates cytokine and gene expression profiles in the brain after wholebody exposure to radiation. In Vivo 28: 21-32, 2014.

22 Obata K, Shimo T, Okui T, Matsumoto K, Takada H, Takabatake $\mathrm{K}$, Kunisada $\mathrm{Y}$, Ibaragi S, Nagatsuka $\mathrm{H}$ and Sasaki A: Tachykinin Receptor 3 Distribution in Human Oral Squamous Cell Carcinoma. Anticancer Res 36: 6335-6341, 2016.

23 Patacchini R, Lecci A, Holzer P and Maggi CA: Newly discovered tachykinins raise new questions about their peripheral roles and the tachykinin nomenclature. Trends Pharmacol Sci 25: 1-3, 2004.

24 Nelson D and Bost KL: Quantification of hemokinin-1 peptide production and secretion from mouse B cells. Cell Immunol 237: 115-122, 2005.

25 Almeida TA, Rojo J, Nieto PM, Pinto FM, Hernandez M, Martin JD and Candenas ML: Tachykinins and tachykinin receptors: structure and activity relationships. Cur Med Chem 11: 20452081, 2004.
26 Källback P, Shariatgorji M, Nilsson A and Andrén PE: Novel mass spectrometry imaging software assisting labeled normalization and quantitation of drugs and neuropeptides directly in tissue sections. J Proteomics 75: 4941-4951, 2012.

27 Wei H, Nolkrantz K, Parkin MC, Chisolm CN, O'Callaghan JP and Kennedy RT: Identification and quantification of neuropeptides in brain tissue by capillary liquid chromatography coupled off-line to MALDI-TOF and MALDI-TOF/TOF-MS. Anal Chem 78: 4342-4351, 2006.

28 Helbig AO, Gauci S, Raijmakers R, Van Breukelen B, Slijper M, Mohammed S and Heck AJR: Profiling of $\mathrm{N}$-acetylated protein termini provides in-depth insights into the $\mathrm{N}$-terminal nature of the proteome. Mol Cell Proteomics 9: 928-939, 2010.

29 Walsh CT, Garneau-Tsodikova S and Gatto GJ: Protein posttranslational modifications: the chemistry of proteome diversifications. Angew Chemie Int Ed 44: 7342-7372, 2005.

30 Zhang X, Petruzziello F, Zani F, Fouillen L, Andren PE, Solinas $G$ and Rainer G: High identification rates of endogenous neuropeptides from mouse brain. J Proteome Res 11: 28192827, 2012.

31 Wilkinson CW: Roles of acetylation and other post-translational modifications in melanocortin function and interactions with endorphins. Peptides 27: 453-471, 2006.

32 Van Dijck A, Hayakawa E, Landuyt B, Baggerman G, Van Dam D, Luyten W, Schoofs L and De Deyn PP: Comparison of extraction methods for peptidomics analysis of mouse brain tissue. J Neurosci Methods 197: 231-237, 2011.

33 Van den Pol AN: Neuropeptide transmission in brain circuits. Neuron 76: 98-115, 2012
Received July 16, 2017

Revised August 3, 2017

Accepted August 4, 2017 